É de realçar que a terceira edição do congresso ISySyCat superou os seus objetivos e foi um sucesso. 0 feedback recebido dos congressistas durante e após o congresso foi extremamente positivo e motivador para se proceder à organização da quarta edição do ISySyCat já em 2021, o ISySyCat2021, entre 31 de agosto e 3 de setembro em Évora.

A Comissão Organizadora agradece a todas as pessoas e entidades que colaboraram, tornaram possível e contribuíram indubitavelmente para o sucesso deste congresso, nomeadamente, os patrocinadores e instituições que apoiaram o evento. Uma palavra de reconhecido agradecimento é devida à Universidade de Évora e à Sociedade Portuguesa de Química. Por último, um agradecimento a todos os participantes que, com as suas contribuições, garantiram a qualidade do International Symposium on Synthesis and Catalysis (ISySyCat2019).

Mais informações sobre o congresso podem ser consultadas em cat2019.eventos.chemistry.pt.

$>$

A Comissão Organizadora

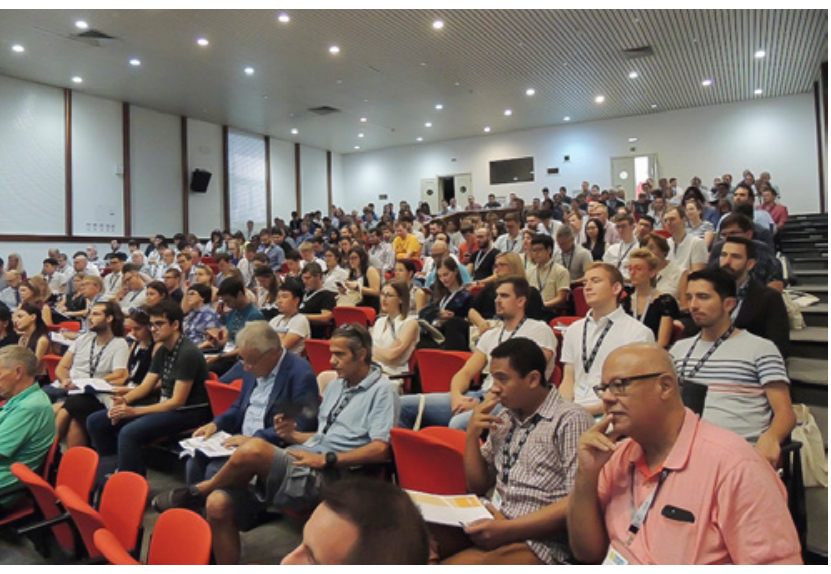

Visão geral do auditório principal durante uma sessão do congresso

\section{Euroanalysis 2019 Conference}

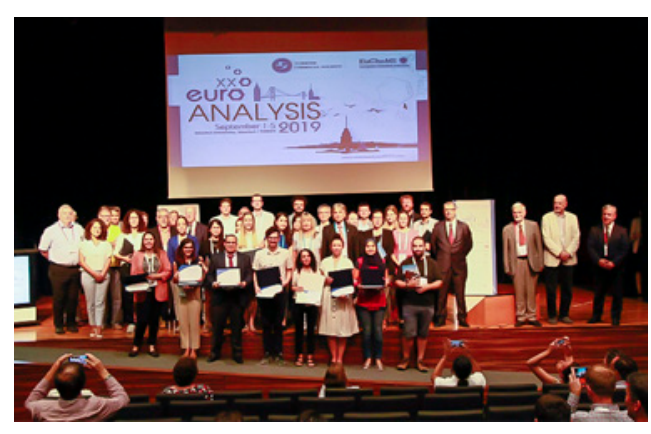

O congresso EUROANALYSIS 2019 (20 th edition) decorreu entre 1 e 5 de setembro de 2019 em lstambul, Turquia. Este congresso, organizado sob a égide da Divisão de Química Analítica da EuChems - European Chemical Society, é considerado o grande congresso europeu da Química Analítica, tendo por isso abrangido uma grande variedade de temas, focando novos desenvolvimentos na área assim como aplicações inovadoras. Destacam-se a conferência plenária proferida pelo recipiente do DAC-EuCheMS Award - Prof. Freddy Adams, com o título "The Metamorphosis of Analytical Chemistry: chemical analysis in the $21^{\text {st }}$ century" e a distinção Robert Kellner Lecture, atribuída à Prof. Luisa Torsi, que proferiu uma lição sobre "Single-molecule sensing of clinical biomarkers". 0 programa englobou ainda mais 12 lições plenárias, 39 lições convidadas (keynotes), cerca de 160 comunicações orais (das quais 60 foram apresentadas por jovens investigadores) e cerca de 320 painéis. A participação correspondeu à abrangência dos temas, tendo sido registados cerca de 600 participantes de mais de 50 nacionalidades diferentes. A comunidade portuguesa também esteve presente, com 14 participantes registados. O próximo congresso EUROANALYSIS terá lugar em Nijmegen, nos Países Baixos, entre 22 e 27 de agosto de 2021 (www.euroanalysis2021.nl).

$>$

\section{Marcela Segundo}

msegundo@ff.up.pt 